\title{
Nitrate, Chloride and Calcium Contamination of Hand-dug Well Water from Household Pit-latrine in Asamankese, Eastern Ghana
}

\author{
Ayaana Umar Karim', Yaa Ntiamoa-Baidu ${ }^{2}$, Joseph Addo Ampofo ${ }^{3}$, Robert Kingsford-Adaboh ${ }^{4, *}$ \\ ${ }^{1}$ Institute of Environmental and Sanitation Studies, University of Ghana, Ghana \\ ${ }^{2}$ Department of Animal Biology and Conservational Science, University of Ghana, Ghana \\ ${ }^{3}$ Water Research Institute, Center for Scientific and Industrial Research, Ghana \\ ${ }^{4}$ Department of Chemistry, University of Ghana, Ghana \\ *Corresponding Author: kadabohs@ug.edu.gh
}

Copyright $@ 2015$ Horizon Research Publishing All rights reserved.

\begin{abstract}
The aim of this study was to assess nitrate, chloride and calcium contamination in hand-dug well water as a result of effluent infiltration from household pit-latrine. The study also compared wet and dry season effluent contamination levels. The results were compared to the natural background levels, Ghana Standard Board (GSB) and World Health Organization (WHO) guideline limits for drinking water. Generally, the result of the study indicated a $100 \%$ contamination of water with nitrate $\left(\mathrm{NO}_{3}{ }^{-}\right)$, chloride $\left(\mathrm{Cl}^{-}\right)$and Calcium $\left(\mathrm{Ca}^{2+}\right)$ beyond the natural background of $0.23 \mathrm{mg} / \mathrm{l}, 7.8 \mathrm{mg} / \mathrm{l}$ and $12 \mathrm{mg} / 1$ respectively for safe drinking water. In addition, $21.7 \%$ and $8.3 \%$ of the samples analysed for nitrate and chloride respectively, were contaminated at levels that could pose serious health hazards. This could be attributed to the effluent leachate infiltration from the household pit-latrine through the soil into nearby hand-dug well water. Nitrate cannot be retained by soil and is easily washed out of the soil by percolating water. Sodium chloride, a common ingredient in the diet of most Ghanaians, is a strong electrolyte and passes through the digestive system unchanged. Chloride is therefore used as a measure of the extent of sewage discharge into water bodies. Analysis of variance at $95 \%$ confidence interval showed that calcium significantly differed in temporal variation $(p=0.00)$, chloride significantly differed in spatial variation while nitrate was significantly different in both spatial and temporal variations. It is recommended that the West Akim Municipal Assembly and Ghana Health Service should conduct regular inspections and monitor the construction of pit-latrines in the various households.
\end{abstract}

Keywords Contamination, Effluent Leachate, Methaemoglobinaemia, Triholomethanes, Liver Carcinogen

\section{Introduction}

The crucial role groundwater plays as a decentralized source of drinking water for millions of people in rural and urban communities in Ghana cannot be overlooked. According to the Ghana Living Standard Survey (GLSS) [1], a greater majority (47\%) of rural households depends on well water for their daily activities. In recent years, widespread reports of nitrate, chloride, calcium and other pollutants in groundwater have increased public concern about the quality of groundwater. Moody [2] observed that the most prominent cause of groundwater pollution is effluent leachate from pit latrines. According to World Health Organization (WHO) and the United Nations International Children and Education Fund (UNICEF) [3] world health report, an estimated 42,000 people die each week from diseases linked to unsafe water and lack of sanitation, of which $90 \%$ are children under five years of age. What is more, every year, unsafe water coupled with lack of sanitation, kills at least 1.6 million children under the ages of five years. This is more than 8 times the number of people who died in the Asian tsunami of 2004 [4].

To avoid groundwater pollution from effluent leachate, the Community Water and Sanitation Agency (CWSA) recommends that pit latrines should be constructed at least 100 feet $(30 \mathrm{~m})$ downhill of boreholes [5]. In addition, WHO [6] asserted that a minimum of 50 feet $(15 \mathrm{~m})$ between a pollution source and a downstream water abstraction point will be satisfactory.

However, reconnaissance survey conducted at the study area prior to the study revealed that generally pit latrines have been built within the homestead very close to hand-dug wells. The possibility of groundwater pollution due to seepage through lateral movement of water in the soil cannot be ruled out. It is against this background that this research was conducted at Asamankese Municipality, which, according to the Ghana Statistical Service survey (GSS) [7] is the second highest municipality dependent on pit latrines (44\%) in Ghana after Suhum-Kraboa Coaltar (56.2\%). The 
objectives of the study were primarily to investigate the level of contamination of nitrate, chloride and calcium in hand-dug well water and determine their seasonal variations in concentration. The study also sought to relate the levels of contamination to lateral distances between pit latrine and hand-dug well.

\section{Materials and Methods}

\subsection{Study Area}

The study was carried out at Asamankese. Asamankese is the capital of West Akim Metropolitan Assembly in the Eastern Region of Ghana and lies between longitudes $0^{\circ} 25^{\prime}$ West and $0^{\circ} 47^{\prime}$ West and latitudes $5^{\circ} 40^{\prime}$ North and $6^{\circ} 00^{\prime}$ North, covering a total land area of about 1,018 square $\mathrm{km}$. It is about $75 \mathrm{~km}$ North-West of Accra [8]. A map of Asamankese township showing all the sampled sites is presented in Figure 1.

The total population of Asamankese is 34,855 persons representing $4.7 \%$ of Eastern region and $22.6 \%$ of the metropolis. Asamankese is the fourth highest populated town in Eastern Region after Koforidua (11.9\%), Nkawkaw (6.0\%) and Akim Oda (5.3\%). West Akim Metropolis (Asamankese) has the highest percentage (35.1\%) of well water sources in the Eastern region and it is followed closely by Birim South District- Akwatia (34.5\%) and Afram Plains with the least percentage $(4.9 \%)$. The pit latrine inside the dwelling unit is the commonest type of toilet facility, used by $37.5 \%$ i.e. more than $1 / 3$ of the household in the region while $28.9 \%$ of the household use public toilet which could be WC, KVIP, pit, pan, etc. [7].

\subsection{Geology of the Study Area}

The district is under-lain with Granite and Birimian rock formation, rich in natural resources such as gold, clay deposits, diamonds and water resources. The soils of the district are: the Kumasi-Asuansi-Nta-Ofin, Nsaba-Swedru-Nta-Ofin and Bekwai-Nzima-Oda; Atewa/Ansum, Adawso-Bawjiasi/Nta-Ofin, Atewiredu-Kate and Atukrom-Asikuma-Ansum; Yaya-Bediasi/Bejua,
Nyanao-Atinkong/Opimo and Pimpimso-Sutawa/Bejua and Chichiwere-Ayensu/Kankum and Amo-Tefle. The land is naturally undulating with heights ranging between 60 and $460 \mathrm{~m}$ above sea level [8].

Table 1. Percentage Distribution of Water Sources and Toilet Facilities in the metropolis

\begin{tabular}{|c|c|c|c|}
\hline $\begin{array}{c}\text { Drinking Water } \\
\text { Facilities }\end{array}$ & $\begin{array}{c}\text { Percentage } \\
(\%)\end{array}$ & Toilet facilities & $\begin{array}{c}\text { Percentage } \\
(\%)\end{array}$ \\
\hline Well & 35.1 & $\begin{array}{c}\text { Water Closet } \\
\text { (WC) }\end{array}$ & 1.1 \\
\hline River/Stream & 33.1 & Pit Latrine & 44 \\
\hline Pipe-borne (inside) & 2.0 & KVIP & 7.8 \\
\hline Pipe-borne (outside) & 9.0 & Bucket/Pan & 1.8 \\
\hline Tanker Supply & 0.3 & Facility in & 4.0 \\
\hline Borehole & 13.0 & Public Toilet & 37.1 \\
\hline Spring/Rainwater & 4.0 & No facility & 4.1 \\
\hline Dugout & 3.3 & Other & 0.1 \\
\hline Others & 0.1 & & \\
\hline
\end{tabular}

Adapted from GSS [7] and WADA [8].

\subsection{Sampling of sites and site description}

Eight sampling points were selected for analysis of various water quality parameters. Global positions (coordinate) of the various sampling points were taken using GARMIN 45 GPS. The sampled points are indicated in figure 1. Based on common characteristics such as lateral distance between wells and pit latrines and modes of constructions, the sampled wells were categorized into two. Category A wells (main experimental block) are group of wells that have lateral distance from pit latrine below the recommended distances of $50 \mathrm{ft}(15 \mathrm{~m})$ for WHO [6] and $100 \mathrm{ft}(30 \mathrm{~m})$ for Ghana's CWSA [5]. Category B wells (controlled experimental block) are group of wells whose lateral distance from pit latrine is more than the WHO and Ghana's CWSA recommended distances. Detailed description of sampling sites is given in table 2. Figure 2 and 3 give the general profile of pit latrines and sampled station ASA 3A respectively. 


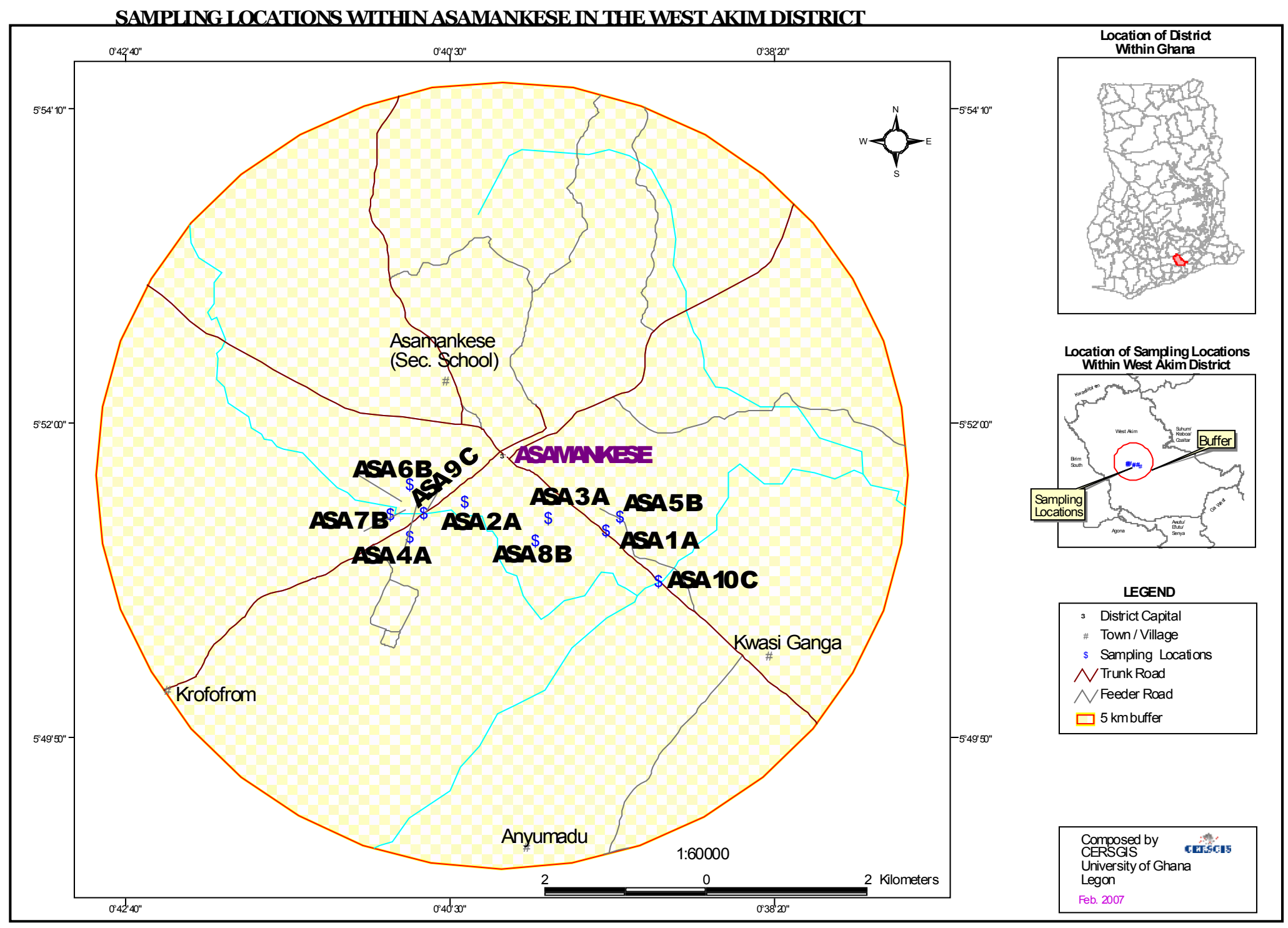

Figure 1. Map of Study area. [Source: CERGIS, University of Ghana]. 
Nitrate, Chloride and Calcium Contamination of Hand-dug Well Water from Household Pit-latrine in Asamankese, Eastern Ghana

Table 2. Detailed Description of Sampled Sites

\begin{tabular}{|c|c|c|c|}
\hline $\begin{array}{l}\text { Sampled } \\
\text { Sites }\end{array}$ & $\begin{array}{l}\text { GPS coordinates } \\
\text { Latitude/Longitude }\end{array}$ & $\begin{array}{l}\text { Lateral distance } \\
\text { from pit latrine }\end{array}$ & Well construction details \\
\hline \multicolumn{4}{|l|}{ Category A } \\
\hline ASA $1^{\mathrm{A}}$ & $\begin{array}{l}\text { N } 05^{\circ} 51^{\prime} 14.9^{\prime \prime} \\
\text { W } 000^{\circ} 39^{\prime} 26.9^{\prime \prime}\end{array}$ & $\begin{array}{c}5 \mathrm{~m} \text { downstream of pit } \\
\text { latrine }\end{array}$ & $\begin{array}{c}\text { Depth of well: } 7 \text { m deep well. } \\
\text { Bore construction: poorly cemented } \\
\text { Crown cover: present }\end{array}$ \\
\hline $\operatorname{ASA} 2^{\mathrm{A}}$ & $\begin{array}{l}\text { N } 05^{\circ} 51^{\prime} 25.6^{\prime \prime} \\
\text { W } 000^{\circ} 40^{\prime} 30.6^{\prime \prime}\end{array}$ & $\begin{array}{c}3 \mathrm{~m} \text { downstream of pit } \\
\text { latrine }\end{array}$ & $\begin{array}{c}\text { Depth of well: } 4 \mathrm{~m} \text { shallow well. } \\
\text { Bore construction: not cemented } \\
\text { Crown cover: absent }\end{array}$ \\
\hline $\begin{array}{c}\text { ASA } 3^{\mathrm{A}} \\
\text { (see fig. 2) }\end{array}$ & $\begin{array}{l}\text { N } 05^{\circ} 51^{\prime} 20.2^{\prime \prime} \\
\text { W } 000^{\circ} 39^{\prime} 50.1^{\prime \prime}\end{array}$ & $\begin{array}{c}5 \mathrm{~m} \text { downstream of pit } \\
\text { latrine. }\end{array}$ & $\begin{array}{l}\text { Depth of well: } 3 \mathrm{~m} \text { shallow well. } \\
\text { Bore construction: cemented } \\
\text { Crown cover: present }\end{array}$ \\
\hline $\operatorname{ASA} 4^{\mathrm{A}}$ & $\begin{array}{l}\mathrm{N} 05^{\circ} 51^{\prime} 23.5^{\prime \prime} \\
\mathrm{W} 000^{\circ} 40^{\prime} 42.1^{\prime \prime}\end{array}$ & $\begin{array}{c}5.5 \mathrm{~m} \text { downstream of pit } \\
\text { latrine. }\end{array}$ & $\begin{array}{l}\text { Depth of well: } 4 \text { m shallow well. } \\
\text { Bore construction: cemented } \\
\text { Crown cover: present }\end{array}$ \\
\hline \multicolumn{4}{|l|}{ Category B } \\
\hline ASA $5^{\text {B }}$ & $\begin{array}{l}\text { N } 05^{\circ} 51^{\prime} 20.6^{\prime \prime} \\
\text { W } 000^{\circ} 39^{\prime} 21.3^{\prime \prime}\end{array}$ & $\begin{array}{c}35.0 \mathrm{~m} \text { downstream of pit } \\
\text { latrine. }\end{array}$ & $\begin{array}{l}\text { Depth of well: } 4 \mathrm{~m} \text { shallow well. } \\
\text { Bore construction: not cemented } \\
\text { Crown cover: absent }\end{array}$ \\
\hline ASA $6^{\text {B }}$ & $\begin{array}{l}\mathrm{N} 05^{\circ} 51^{\prime} 23.2^{\prime \prime} \\
\mathrm{W} 000^{\circ} 40^{\prime} 44.6^{\prime \prime}\end{array}$ & $\begin{array}{l}36.0 \mathrm{~m} \text { downstream of pit } \\
\text { latrine }\end{array}$ & $\begin{array}{l}\text { Depth of well: } 3 \mathrm{~m} \text { shallow well. } \\
\text { Bore construction: cemented } \\
\text { Crown cover: present }\end{array}$ \\
\hline ASA $7^{\mathrm{B}}$ & $\begin{array}{l}\text { N } 05^{\circ} 51^{\prime} 24.2^{\prime \prime} \\
\text { W } 000^{\circ} 40^{\prime} 43.9^{\prime \prime}\end{array}$ & $\begin{array}{c}35.5 \mathrm{~m} \text { downstream of pit } \\
\text { latrine }\end{array}$ & $\begin{array}{l}\text { Depth of well: } 5 \text { m deep well. } \\
\text { Bore construction: cemented } \\
\text { Crown cover: absent }\end{array}$ \\
\hline ASA $8^{\text {B }}$ & $\begin{array}{l}\mathrm{N} 05^{\circ} 51^{\prime} 11.0^{\prime \prime} \\
\mathrm{W} 000^{\circ} 39^{\prime} 55.1^{\prime \prime}\end{array}$ & $\begin{array}{l}36.0 \mathrm{~m} \text { downstream of pit } \\
\text { latrine. }\end{array}$ & $\begin{array}{l}\text { Depth of well: } 5 \mathrm{~m} \text { deep well. } \\
\text { Bore construction: cemented } \\
\text { Crown cover: present }\end{array}$ \\
\hline
\end{tabular}

\section{General Profile of Pit Latrine in the Study Area}
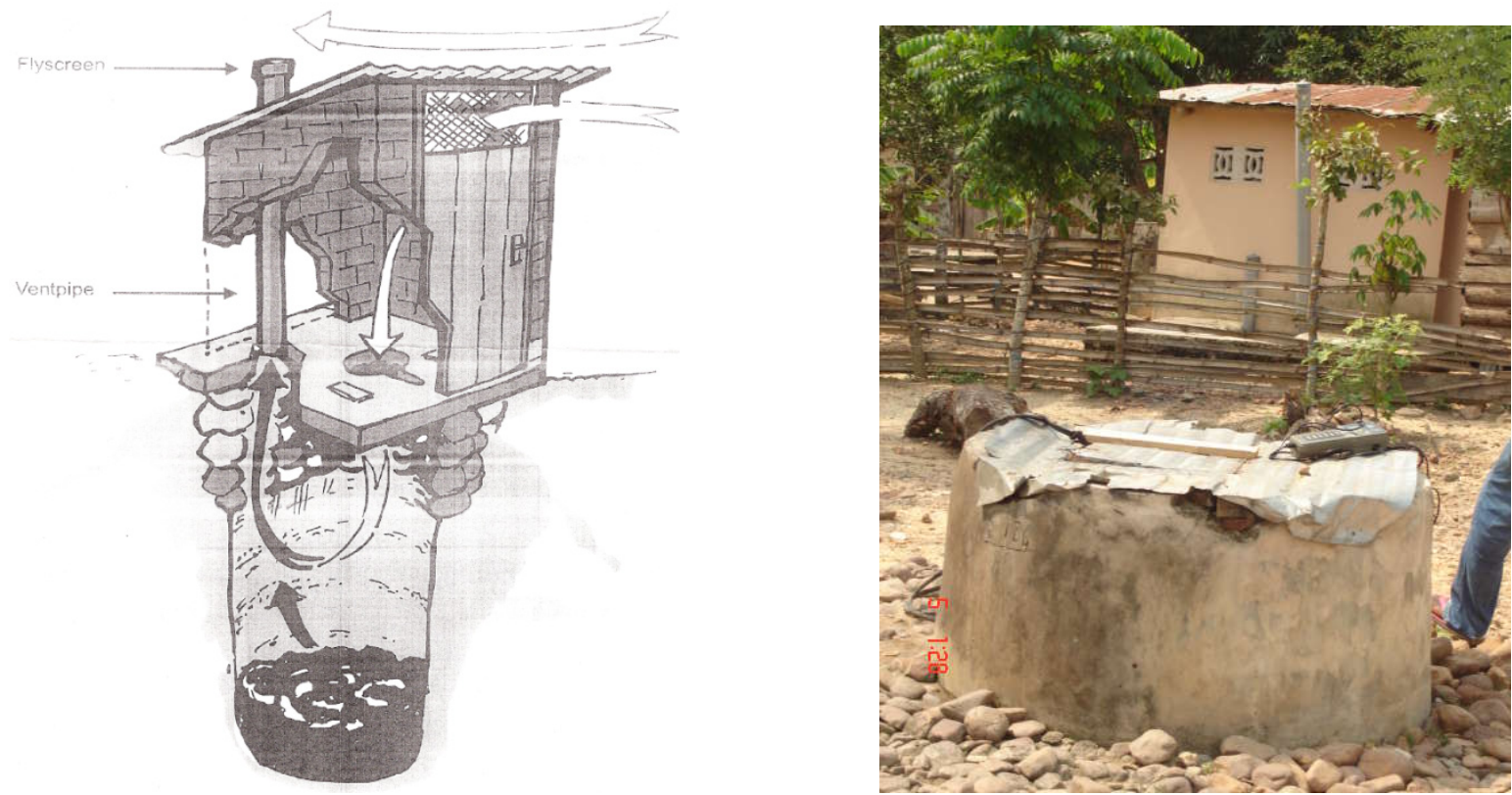

[Source: Adapted from CWSA [5]]

Figure 2. Profile of Pit Latrine in the study area

Figure 3. Sampled Station ASA 3 A showing the lateral distance between pit latrine and well 


\subsection{Sampling Parameters}

Nitrate $\left(\mathrm{NO}_{3}{ }^{-}\right)$, chloride $\left(\mathrm{Cl}^{-}\right)$and calcium $\left(\mathrm{Ca}^{2+}\right)$ were the principal parameter sampled for analysis. Conductivity, alkalinity and total dissolved solids (TDS) were also sampled for analysis as secondary parameters because of their direct influence on the principal parameters.

\subsection{Sampling of Water}

Purging is the process of removing stagnant water from a bore before sampling. Purging aims to enable the extraction of samples that are representatives of aquifer formation water while creating minimal disturbances to the groundwater flow regime [9].

At any sampling period, purging was done gently using a clean treated bailer until parameters such as $\mathrm{pH}$, temperature, electrical conductivity, dissolved oxygen (DO) and turbidity became stabilized. Stagnant water is said to have been removed at this stage. The parameters were considered stable when three consecutive readings were within:

$$
\begin{aligned}
& \pm 10 \% \text { for } \mathrm{DO} \\
& \pm 10 \% \text { for turbidity } \\
& \pm 3 \% \text { for electrical conductivity } \\
& \pm 0.05 \% \text { for } \mathrm{pH}[10,11] .
\end{aligned}
$$

After purging of wells, water sampler was used to collect water from each well into a clean and treated 1.5 litre plastic bottle for physico-chemical analysis.

\subsection{Sample Treatment, Precautions and Material}

According to the WHO [12] the result of physico-chemical analysis are of no value if the samples tested are not properly collected and stored. The following treatment and precautions were taken during field work and laboratory analysis:

- Sampling containers, mainly, water samplers, bailers, plastic buckets and sampling bottles with their well-fitting stoppers were pre-treated by washing with acetone to get rid of organic substances such as grease and fat residues. They were then washed with detergent and rinsed with de-ionised water and steeped in $1.6 \mathrm{M}$ nitric acid solution for three days. They were again washed thoroughly with de-ionised water and filled with acidified water. The water is discarded at the point of sampling and washed several times with water to be sampled [13].

- Conductivity was taken in-situ after several measurements to obtain stable values. This was necessary because conductivity easily changes in quality during handling, transportation and storage.

- Sterilized 1.5 litre plastic bottles were used for the collection and storage of water samples for the analysis of nitrate, chloride, calcium, alkalinity and TDS

\subsection{Laboratory Analysis of Water Quality Parameters}

Field and laboratory analysis of the various parameters were done following the internationally accepted methods set out by $\mathrm{HACH}[14,15]$. Other standards that were adhered to during sampling and analysis included those set out by the WHO [12,16]; APHA, AWWA, WEF [17]; UNESCO/WHO [18] and the Association of Official Analytical Chemists (AOAC) [19].

\subsection{Statistical Analysis of Data}

Data collected were analysed using the following computer softwares: Statistical Package for Social Scientist (SPSS) version 11.0 and Microsoft Excel Windows XP version. The SPSS was used to run Analysis of Variance (One-way ANOVA) at 95\% confidence interval to determine the significance levels of parameters in both spatial (between wells and pit latrines) and seasonal variations. $\mathrm{P} \leq 0.05$ are significantly different while $\mathrm{P} \geq 0.05$ are not significantly different.

Natural Background Limits, GSB and WHO standards for unpolluted water were used as bench marks to determine the state of pollution of the various parameters. The natural background levels represent the concentration levels of the parameters in unpolluted water while the GSB and WHO guideline values normally represents the concentration of a constituent that does not result in any significant risk to

\begin{tabular}{|c|c|c|c|c|c|c|c|c|c|}
\hline \multirow{2}{*}{$\begin{array}{c}\text { Water Quality } \\
\text { Parameter }\end{array}$} & \multicolumn{9}{|c|}{ Sampled sites } \\
\hline & Seasons & ASA $1^{\mathrm{A}}$ & $\operatorname{ASA} 2^{\mathrm{A}}$ & $\mathrm{ASA} 3^{\mathrm{A}}$ & $\operatorname{ASA} 4^{\mathrm{A}}$ & ASA $5^{\mathrm{B}}$ & ASA $6^{\mathrm{B}}$ & $\operatorname{ASA} 7^{\mathrm{B}}$ & ASA $8^{B}$ \\
\hline \multirow{2}{*}{ TDS (mg/l) } & Wet & 452.5 & 152.8 & 701.0 & 142.5 & 251.0 & 248.0 & 251.2 & 109.0 \\
\hline & Dry & 580.0 & 319.3 & 1061.7 & 330.7 & 373.0 & 168.2 & 324.0 & 161.8 \\
\hline \multirow{2}{*}{ Alkalinity (mg/l) } & Wet & 41.5 & 24.4 & 162.8 & 40.6 & 17.6 & 71.0 & 27.6 & 23.6 \\
\hline & Dry & 103.3 & 132.6 & 59.6 & 84.1 & 78.8 & 16.3 & 39.7 & 19.1 \\
\hline \multirow{2}{*}{$\begin{array}{l}\text { Conductivity } \\
(\mu \mathrm{S} / \mathrm{cm})\end{array}$} & Wet & 597.3 & 488.0 & 415.7 & 1036.7 & 201.3 & 227.0 & 455.7 & 212.0 \\
\hline & Dry & 560.0 & 385.7 & 3333.3 & 1370 & 152.0 & 222.0 & 286.3 & 190.7 \\
\hline \multirow{2}{*}{$\mathrm{NO}_{3}^{-}(\mathrm{mg} / \mathrm{l})$} & Wet & 3.5 & 13.0 & 6.8 & 7.5 & 8.1 & 5.2 & 5.6 & 6.6 \\
\hline & Dry & 13.3 & 12.3 & 8.8 & 9.2 & 8.4 & 7.3 & 6.2 & 6.3 \\
\hline \multirow{2}{*}{$\mathrm{Cl}^{-}(\mathrm{mg} / \mathrm{l})$} & Wet & 55.2 & 23.2 & 43.0 & 242.7 & 40.9 & 31.5 & 73.2 & 27.2 \\
\hline & Dry & 120.3 & 45.7 & 48.7 & 301.3 & 48.0 & 42.3 & 51.0 & 40.3 \\
\hline \multirow{2}{*}{$\mathrm{Ca}^{2+}(\mathrm{mg} / \mathrm{l})$} & Wet & 14.8 & 47.0 & 54.7 & 82.6 & 11.5 & 16.8 & 24.3 & 24.1 \\
\hline & Dry & 68.5 & 86.3 & 142.5 & 165.3 & 25.1 & 28.3 & 36.2 & 34.2 \\
\hline
\end{tabular}
health over a lifetime of consumption [20].

The result is presented in tables and graphs.

Table 3. Results of field and laboratory analysis of water quality parameters from the sampled wells 


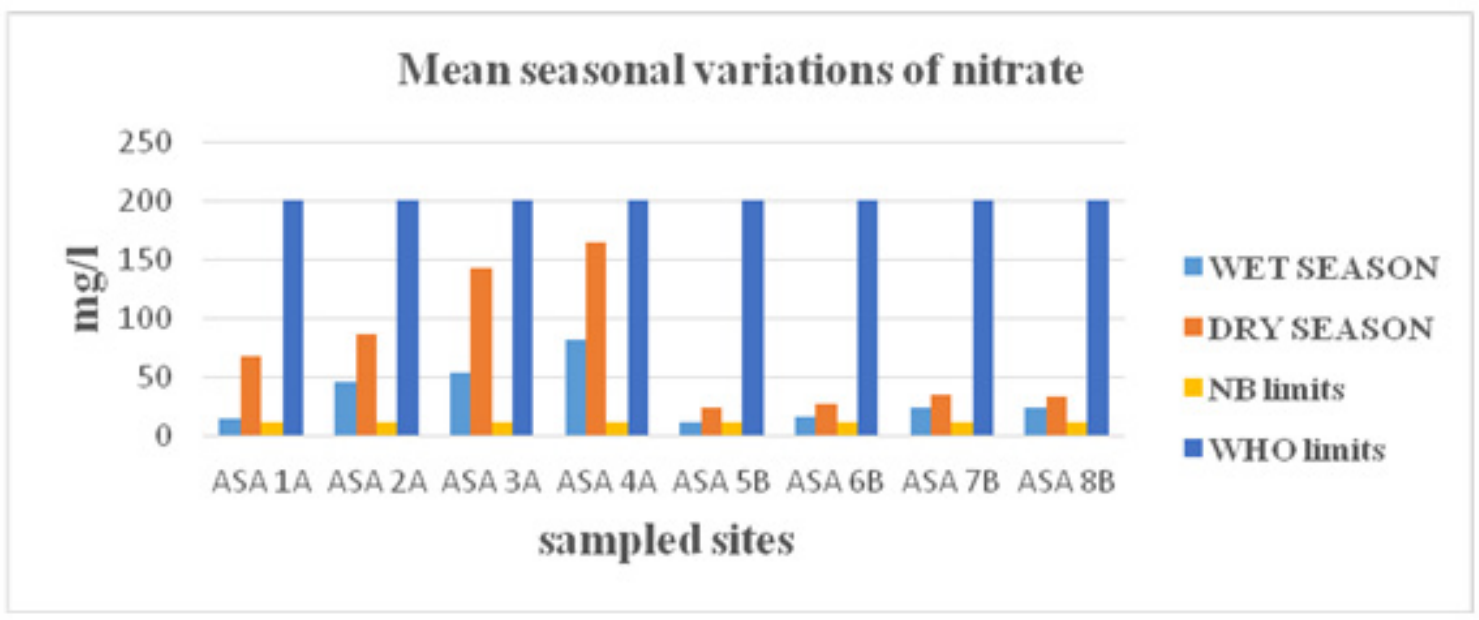

Figure 4. Graphical illustration of mean seasonal variation of nitrate in water

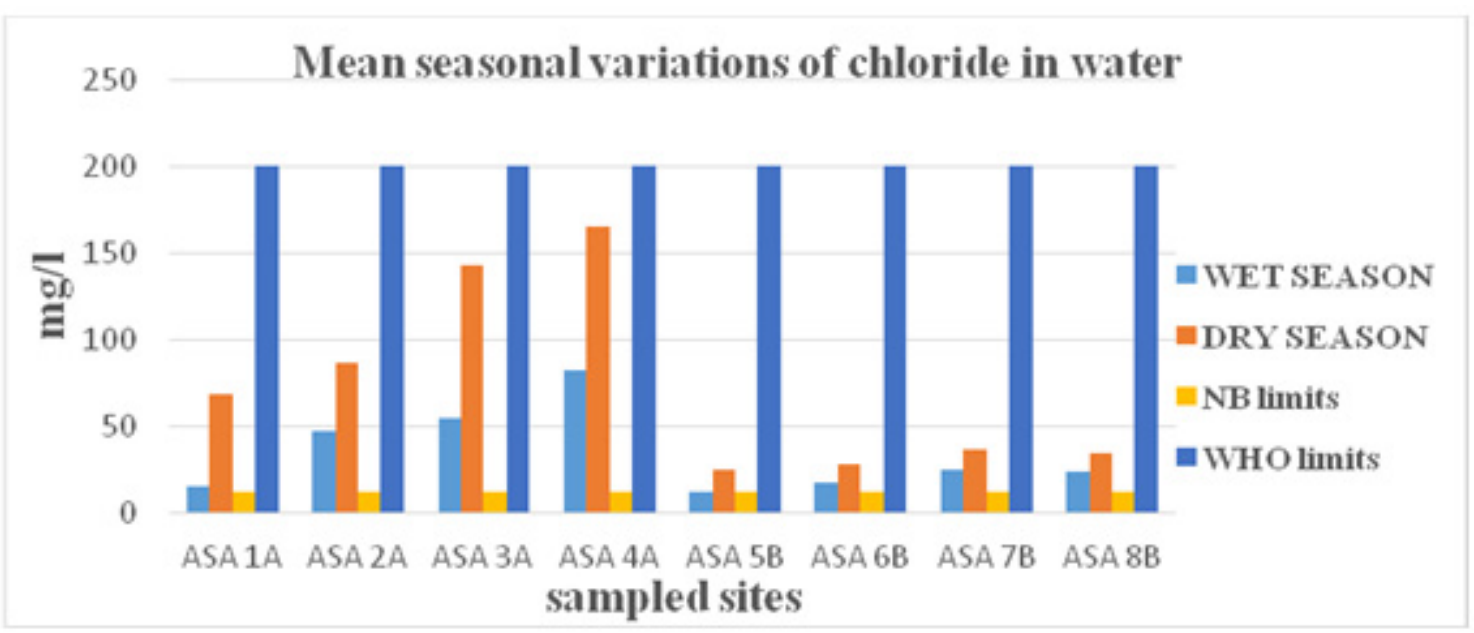

Figure 5. Graphical illustration of mean seasonal variations of chloride in water

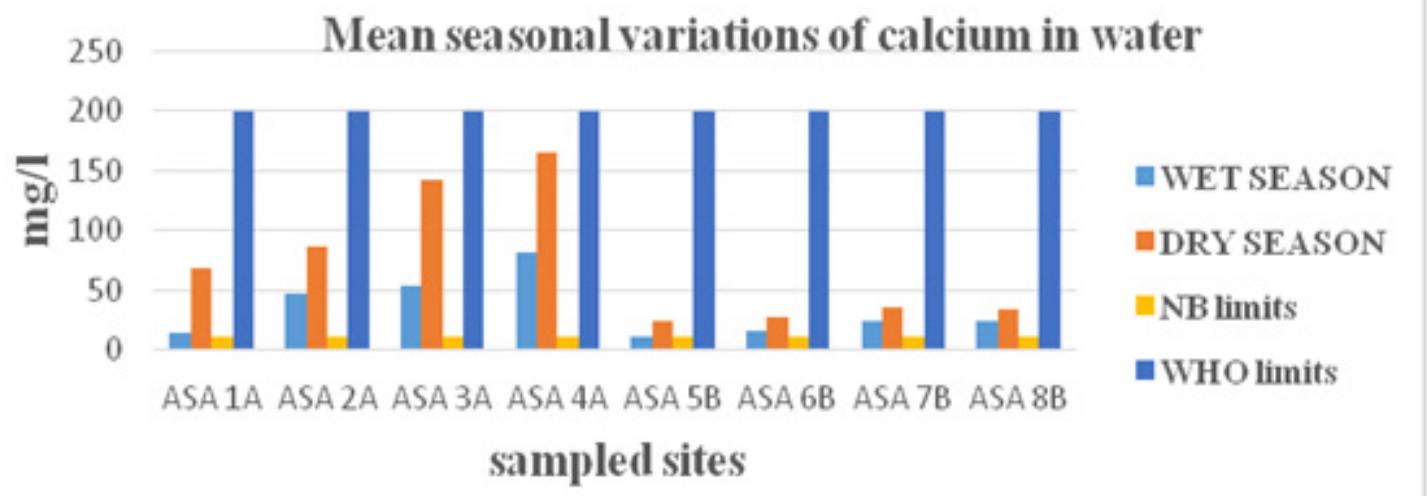

Figure 6. Graphical illustration of mean seasonal variations of calcium in water 


\section{Results and Discussion}

Alkalinity values recorded over the entire study period were below the GSB limits of $400 \mathrm{mg} \mathrm{L}^{-1}$ for drinking water. These relatively low levels of alkalinity indicate that the waters are well buffered.

Conductance of water was found to be high. Fifty one percent of the samples tested for conductivity reflected pollution above the natural background concentration level of $300 \mathrm{mg} / \mathrm{l}$. WHO guideline limit for conductivity is unavailable for comparison. High conductivity influences the dissolution of ions such as $\mathrm{Cl}^{-}, \mathrm{NO}_{3}{ }^{-}, \mathrm{SO}_{4}{ }^{3-}, \mathrm{PO}_{4}{ }^{3-}$ and $\mathrm{Ca}^{2+}$ present in sewage into water [21]. Analysis of variance at $95 \%$ confidence interval showed a significant differences in spatial variation $(\mathrm{p}=0.000)$. Site $\mathrm{ASA} 1^{\mathrm{A}}$ and $\mathrm{ASA} 4^{\mathrm{A}}$ (i.e. Category A wells) were significantly different from all other sites.

Nitrate in addition to its health hazards is a major indicator of the rate of effluent infiltration through the soil. According to Lester and Birkett [22], nitrate cannot be retained by soil and is easily washed out of the soil by percolating water. Generally, mean seasonal values obtained for $\mathrm{NO}_{3}{ }^{-}$were far above the natural background concentration limit of 0.23 $\mathrm{mg} / \mathrm{l}$ for safe drinking water but slightly below the WHO limits of $10 \mathrm{mg} / \mathrm{l}$ excepts for sites ASA $1^{\mathrm{A}}(13.3 \mathrm{mg} / \mathrm{l}$ in the dry season), ASA $2^{\mathrm{A}}(12.3 \& 13.0 \mathrm{mg} / \mathrm{l}$ in the dry and wet seasons respectively). There was $100 \%$ contamination of $\mathrm{NO}_{3}{ }^{-}$beyond the natural background limits for safe drinking water. In addition, $18.75 \%$ of the samples analysed for $\mathrm{NO}_{3}^{-}$ were contaminated at levels that are beyond the WHO guideline limits. Thus, these levels could pose serious health hazards. In a similar study on the 'Effect of Sanitation Systems on Groundwater', Ahmed [23] recorded very high nitrate concentrations in the ranges of $59-98 \mathrm{mg} / \mathrm{l}^{1}$ for wells that are $6 \mathrm{ft}(1.8 \mathrm{~m})$ close to pit latrine. Chidavaenzi et al [24], also observed that nitrate concentrations decreased with increasing lateral distances between wells and pit latrines. Analysis of variance at $95 \%$ confidence interval showed significant differences in both spatial $(p=0.000)$ and temporal $(p=0.001)$ variations. Category A wells especially sampled sites ASA $1^{\mathrm{A}}$ and ASA $2^{\mathrm{A}}$ were significantly higher than other sites.

Sodium chloride, a common ingredient in the diet of most Ghanaians, is a strong electrolyte and passes through the digestive system unchanged. Chloride is, therefore, used in the assessment of water quality as an indication of possible faecal contamination or as a measure of the extent of sewage discharge into water bodies [25]. Thus, high $\mathrm{Cl}^{-}$levels in water indicates high rate of infiltration of other effluent within the soil. Analysis of variance at 95\% confidence interval showed significant differences in spatial variation $(\mathrm{p}$ $=0.000)$ but not in temporal variation $(p=0.632)$. Category A wells, mainly, sampled sites ASA $1^{\mathrm{A}} \& 4^{\mathrm{A}}$ had $\mathrm{Cl}^{-}$ concentrations significantly higher than all the other sites. Although, $\mathrm{Cl}^{-}$concentrations were within the WHO guideline limit $(250 \mathrm{mg} / \mathrm{l})$ for drinking water, all the values recorded were higher than the natural background limits $(7.8$ $\mathrm{mg} / \mathrm{l})$ for safe drinking water.

There was $93.75 \%$ contamination of $\mathrm{Ca}^{2+}$ beyond the natural background concentration limit of $12.0 \mathrm{mg} / 1$ for safe drinking water. However, $\mathrm{Ca}^{2+}$ concentrations in the sampled water were within the WHO and GSB guideline limits of 200 $\mathrm{mg} / \mathrm{l}$. Analysis of variance at $95 \%$ confidence interval showed significant differences in temporal variation $(\mathrm{p}=$ $0.000)$ but not in spatial variation $(p=0.079)$. The major source of $\mathrm{Ca}^{2+}$ in water include weathering of rocks, detergents and human excreta. Although no serious health effects could be associated with calcium, increased calcium concentration in water leads to scaling and water hardness. The presence of multivalent cations such as $\mathrm{Ca}^{2+}$ and $\mathrm{Mg}^{2+}$ in water is noted to increase adsorption capacity of water due to formation of salt bridges between negatively charged microorganisms and soil particles [26]. This means that $\mathrm{Ca}^{2+}$ may increase the concentrations of other nutrients and microorganisms in water.

\section{Conclusions and Recommendations}

There is a clear trend in the concentration of various parameters analysed. Concentrations of the various water quality parameters in the water are significantly higher in Category A wells than in Category B wells. This could be attributed to the infiltration of sewage effluent from nearby household pit-latrine into well water and are aggravated by the inability of the bore casing in the wells to retain nitrate. The most mobile contaminants from on-site sanitation are nitrate and chloride [27]. Nitrate, $\mathrm{Cl}^{-}, \mathrm{Ca}^{2+}$ and TDS were significantly high in the dry season especially in November and December.

There are positive correlations between all the principal parameters for this studies $\left(\mathrm{NO}_{3}^{-}, \mathrm{Cl}^{-}\right.$and $\left.\mathrm{Ca}^{2+}\right)$ with conductivity, TDS and alkalinity. These positive correlations imply that conductivity influenced the dissolution of ions such as $\mathrm{Cl}^{-}, \mathrm{NO}_{3}{ }^{-}, \mathrm{SO}_{4}{ }^{3-}, \mathrm{PO}_{4}{ }^{3-}$ and $\mathrm{Ca}^{2+}$ present in sewage into water [23]; In addition, bulk of the TDS came from ions such as $\mathrm{NO}_{3}^{-}, \mathrm{Cl}^{-}$and $\mathrm{Ca}^{2+}$ among others [28].

In a relatively low saline water, such as those observed in the study area, a marked change in conductivity as observed in the study area can provide an indication of contamination [26].

Nitrate concentration exceeding $10 \mathrm{mg} / \mathrm{l}$ presents a potential serious public health problem. Water in sampled sites ASA $1^{\mathrm{A}}$ and $2^{\mathrm{A}}$ is highly contaminated with nitrate and may cause diseases like stomach cancer and methaemoglobinaemia (blue-baby syndrome or infantile cyanosis) [30-32]. Excessive enrichment of water bodies with $\mathrm{NO}_{3}^{-}$stimulate excessive algal growth in enormous mass known as algal bloom and causes eutrophication. The biodegradation of this algal bloom leads to increased deposition of silt and organic sediments in water [21]. Eutrophication also causes a reduction in water quality and accelerate aging of water bodies due to rapid depletion of biological oxygen demand (BOD). The resultant effect of 
chloride in water according to Baird [30] is that chloride reacts with organic matter in water to form triholomethanes, notably chloroform $\mathrm{CHCl}_{3}$ which is a suspected liver carcinogen in humans at even low levels.

Generally, $97.9 \%$ of the water samples analysed were contaminated beyond the natural background limits for safe drinking water. In addition, $18.75 \%$ of the water samples contain $\mathrm{NO}_{3}{ }^{-}$that were higher than the $\mathrm{WHO}$ guideline limits of $10 \mathrm{mg} / \mathrm{l} . \mathrm{Ca}^{2+}$ and $\mathrm{Cl}^{-}$were within the WHO guideline limits for safe drinking water.

In conclusion, the Community Water and Sanitation Agency (CWSA) and the Water and Sanitation Units of the metropolitan assemblies in the Ghana should monitor and issue permit for the construction of wells and pit latrines to ensure that the specifications set out in the WHO [6] and Water and Sanitation Handbook [5] for district assemblies are strictly followed to the letter.

\section{Acknowledgements}

This work forms part of the first author's MPhil. degree studies in Environmental Science. The authors wish to express their profound gratitude to the Executive Secretary of Centre for African Wetlands (CAW) and UNDP for funding the research through the Capacity Development for Integrated Water Resources Management in Ghana.

\section{REFERENCES}

[1] Ghana Living Standard Survey, GLSS. (2000). Report of the Fourth Round Ghana Living Standard Survey. GLSS, October, 2000. Accra.

[2] Moody, D.W. (1996). Water Quality and Waste Management. Sources and Extent of Groundwater Contamination. North Carolina Cooperative Extension service publishers. AG-441-4.

[3] WHO/UNICEF (2005). The World Health Report 2005: Make Every Mother and Child Count, WHO, 2005. Retrieved March 3, 2007 on World Wide Web http://www.who.int/whr/2005 en.pdf.

[4] WHO/UNICEF. (2006). Meeting the Millennium Development Goal Drinking Water and Sanitation Target. The Urban and rural Challenge of the Decade. Geneva, Switzerland.

[5] Community Water and Sanitation Agency, CWSA. (2003). Water and sanitation Committee (WATSAN) Handbook. IGIP Consulting Engineers \& Mable Consult. Accra, Ghana. p $63-66$.

[6] WHO. (1992). A Guide to the Development of On-site Sanitation. Part II- Detailed Design, Construction, Operation and Maintenance. Geneva.

[7] Ghana Statistical Service, GSS. (2005). Ghana 2000 Population and Housing Census. Eastern Region, Analysis of District Data and Implications for Planning. GSS, Accra,
Ghana. p. 14-85

[8] West Akim District Assembly, WADA. (2006). Medium-Term District Development Plan for West Akim District. Government of Ghana, Ministry of Local Government, Rural Development and Environment. Asamankese. p. 1-68

[9] EPA (2000). Groundwater Sampling Guidelines. EPA, Victoria. Retrieved March 23, 2007 from the World Wide Web http://www.epa.vic.gov.au.

[10] Puls, R.W. (1995). Use of Low Flow or Passive Sampling techniques for sampling Groundwater', Groundwater Sampling - A Workshop Summary. EPA/600/R-94/205, Washington DC. p 17.

[11] Nielsen, D.M. (1991). Practical handbook of Groundwater Monitoring. Lewis Publishers, New York. p 449.

[12] WHO. (1997). Guideline for Drinking-water Quality. Surveillance and Control of Community Supplies. $2^{\text {nd }}$ ed. Volume 3. WHO, Geneva.

[13] Van Loon, Jon, C. (1985). Selected Method of Trace Metals Analysis. Biological and Environmental Samples. John Wiley \& Sons, New York, USA.

[14] HACH Company Limited. (1994). Microbiology: Systems for Analysis. USA. p. 1-45

[15] HACH Company Limited. (1996). DR/2000 Spectrophotometer procedure Manual. USA. p. 9-165

[16] WHO. (1984). Guideline for Drinking Water Quality. $2^{\text {nd }}$ ed. Vol. 1, WHO. Geneva.

[17] APHA, AWWA, WEF. (1998). Standard Methods for the Examination of Water and Wastewater. $20^{\text {th }}$ ed. American Public Health Association (APHA), American Water Works Association (AWWA), Water Environment Federation (WEF), Washington DC.

[18] WHO/UNESCO. (1978). Water Quality Survey, A Guide for the Collection and Interpretation of Water Quality Data., Prepared by the IHD/WHO working group on the quality of water. UNESCO, Paris. p 335.

[19] Association of Official Analytical Chemists (AOAC), (1990). Official Methods for the Analysis of Water. $15^{\text {th }}$ ed. 1, AOAC Inc., Washington DC.

[20] WHO. (2006). Guideline for the Safe use of Wastewater, Excreta and Greywater. Volume 3 Wastewater and Excreta use in Aquaculture. Geneva, Switzerland.

[21] Chapman, D. (1992). Water Quality Assessment. A Guide to the Use of Biota, Sediments and Water in nvironmental Monitoring. $1^{\text {st }}$ ed. University press, Cambridge, UK. p 584-586.

[22] Lester, J.N. and Birkett. (1992). Microbiology and Chemistry for Environmental Science. Wm. C. Publishers.

[23] Ahmed Hassan (2003). 29 ${ }^{\text {th }}$ WEDC International Conference towards the Millennium Development Goals: Effects of Sanitation Systems on Groundwater. Abuja, Nigeria, 2003.

[24] Chidavaenzi, M., Jere, M. and Bradley, M. (1997). Water and Sanitation for All, Partnerships and Innovations. Pit latrine Effluent infiltration into Groundwater. $23^{\text {rd }}$ WEDC Conference. Durban, South Africa. 
[25] APHA (1998). Standard Methods for the Examination of Water and Wastewater. $20^{\text {th }}$ ed. APHA, Washington DC.

[26] WHO \& Organization for Economic Co-operation and Development, OECD. (2003). Assessing Microbial Safety of Drinking Water. Improving Approaches and methods. IWA Publishers, London, UK.

[27] ARGOSS. (2001). Guidance for Assessing Risk to Groundwater from On-site Sanitation. British Geological Survey Commissioned Report CR/01/142, BGS Keyworth.

[28] Burton, J.D. (1976). Basic properties and processes in estuarine chemistry. Estuarine Chemistry. Academic press, London.

[29] Baird Collin (1995). Environmental Chemistry. $2^{\text {nd }}$ ed. W.H. freeman and Co. New York. p 17- 501

[30] Lewis, W.J., Foster, S.S.D. \& Drasar, B.S. (1982). The Risk of Groundwater Pollution by On-site Sanitation in Developing Countries. IRCWD-Report No. 01/82, IRCWD, Duebendorf, p. 70-79.

[31] McCutcheon, S.C., Martin, J.L. and Barnwell Jr., T.O. (1983). Handbook of Hydrology. McGraw-Hill Inc. New York. 